\title{
BINARY ADSORPTION OF COPPER AND ZINC IONS ON ACIDIFIED BENTONITE CLAY: KINETIC AND EQUILIBRIUM STUDIES
}

\author{
L. B. da SILVA ${ }^{1}$, A. F. ALMEIDA NETO ${ }^{2}$ and M. G. C. da $\operatorname{SILVA}^{2}$ \\ ${ }^{1}$ University of Campinas (UNICAMP), School of Chemical Engineering \\ ${ }^{2}$ University of Campinas (UNICAMP), School of Chemical Engineering, Department of \\ Processes and Products Design \\ Contact e-mail: ambrosio@feq.unicamp.br
}

\begin{abstract}
Industrial wastewaters are often contaminated by heavy metals, which can be very hazardous even at low concentrations. Several techniques for removing heavy metal ions have been used over the last century but their cost has usually been high, leading to the study of adsorption as a very promising, low-cost and simple process for metal removal in the last years. This study aims to investigate adsorption of mixed $\mathrm{Cu}^{2+}$ and $\mathrm{Zn}^{2+}$ ions on chemically treated Fluidgel clay, an alternative adsorbent, regarding kinetics and equilibrium aspects. Kinetic studies have shown a saturation time of the adsorbent of about 30 minutes. Kinetic curves were predicted by pseudofirst order and intraparticle diffusion models, while Langmuir and Langmuir-Freundlich bicomponent models have been adjusted to equilibrium data obtained at $293 \mathrm{~K}, 313 \mathrm{~K}$ and $333 \mathrm{~K}$. Metal removal reached $75.8 \%$ for copper and $62.9 \%$ for zinc.
\end{abstract}

\section{INTRODUCTION}

One of the greatest problems regarding environmental pollution is the contamination of water resources by the disposal of industrial wastewater with high concentrations of heavy metals and their ions. When this concentration exceeds the limits established on legislation, there are often many health risks to living organisms. Moreover, heavy metals are usually highly reactive and bioaccumulative, spreading themselves throughout the food chain, since they are not chemically or biologically degraded by any natural mean (Vieira et al., 2012). Therefore, it is essential to develop and study efficient techniques for treating industrial effluents, in order to reduce the contamination of water, soil and varied environments.

The presence of some heavy metals' ions at low concentrations is very important to vital functions on the human body: copper controls enzymatic activity on skin and connective tissues, and a daily intake of $0.03 \mathrm{mg} / \mathrm{kg}$ for adults assures proper blood formation and iron utilization (Alloway, 1990); zinc is essential for DNA and RNA synthesis. Mercury, for example, has no function in the bodies of either plants or animals (Malavolta, 1994). Higher consumption of those ions may trigger many illnesses, such as gastric ulcer, liver necrosis, nausea, vomit and acute stomachaches.

Among the several existing processes for treatment, adsorption stands out due to its great capacity of removal at low concentrations, in addition to being simple and usually 
inexpensive (Nishikawa et al., 2012). Natural clays present themselves as low-cost, highly available and very promising adsorbents, mainly when submitted to chemical or thermic treatments. The Fluidgel bentonite clay has been approached due to the removal results obtained by other clays from PB-Brazil, such as Bofe clay (Vieira et al., 2010 a, b) and Verde-lodo clay (Almeida Neto et al., 2012). Ther work of Almeida Neto, 2013, has shown good results for calcined Fluidgel on removing copper ions and acidified Fluidgel on removing both copper and zinc ions.

\section{MATERIALS AND METHODS}

\subsection{Adsorbent Preparation}

The clay used was sodic bentonite Fluidgel from PB - Brazil, supplied by Dolomil Ltda. The material was submitted to chemical treatment, which consisted of dispersing $100 \mathrm{~g}$ of clay into $1 \mathrm{~L}$ of a solution of acetic acid 4\%, kept under stirring for 4 hours. The solution was filtered and washed with deionized water. The clay was dried up at $50{ }^{\circ} \mathrm{C}$, grinded to powder and sifted. The powder with diameter lower than $0.075 \mathrm{~mm}$ (200 mesh) was separated and used throughout the studies.

A previous characterization study (Almeida Neto, 2013) shows that the clay used is composed mostly of silicates, dioctahedral smectite structures, aluminum phyllosilicates and quartz, with some traces of iron and magnesium. The material expands 2-3 times in contact with water, due to the sodium commercial treatment.

\subsection{Copper and Zinc Solutions}

The preparation of the bicomponent solutions of copper and zinc, for each experiment, consisted of mixing and diluting previously preparated monocomponent solutions of copper and zinc. The latter solutions were obtained by the dissolution of the salts, respectively, copper nitrate $\left(\mathrm{Cu}\left(\mathrm{NO}_{3}\right)_{2} \cdot 3 \mathrm{H}_{2} \mathrm{O}\right)$ and zinc nitrate $\left(\mathrm{Zn}\left(\mathrm{NO}_{3}\right)_{2} \cdot 6 \mathrm{H}_{2} \mathrm{O}\right)$ in distillated and deionized water.

\subsection{Batch Sorption Procedure}

Each adsorption experiment was performed using $100 \mathrm{~mL}$ of an aqueous solution of copper and zinc ions for every gram of clay.

For each one of the 3 kinetics experiments, there was used $1 \mathrm{~L}$ of a bicomponent solution, each one with a different ionic concentration. The experiments were conducted at room temperature $\left(\approx 25^{\circ} \mathrm{C}\right)$ with constant stirring. The solution $\mathrm{pH}(\approx 4,5)$ was defined by the study of metal speciation (Almeida Neto, 2013) and adjusted with drops of concentrated nitric acid. At specific time intervals, $3.8 \mathrm{~mL}$ solution aliquots were removed. Therefore, the final volume reduction did not surpass $8 \%$ of total volume and did not influence the solution concentration at the end of the essay. Then, the aliquots were centrifuged for 10 minutes at $400 \mathrm{rpm}$. The supernatant liquid was diluted and determined by atomic absorption spectrometry. 
The concentration of the metal ions at every time instant on the solid phase, $q(t)$, were calculated with Equation 1:

$$
q(t)=\frac{V}{m}\left[C_{0}-C(t)\right]
$$

where $V$ is the solution volume in $\mathrm{mL}, m$ is the mass of dry clay used in grams, $t$ is the time in minutes and $C_{0}$ is the initial concentration of the metal ion in solution in mmol. $\mathrm{L}^{-1}$.

The percentage of removal (\%Rem) was obtained through Equation 2:

$$
\% \operatorname{Re} m=\frac{\left[C_{0}-C_{e}\right]}{C_{e}}
$$

where $C_{e}$ is the concentration of the metal ion in solution on equilibrium in mmol.L ${ }^{-1}$.

Equilibrium tests were performed with different concentrations of adsorbate and temperatures under controlled stirring $(150 \mathrm{rpm})$ and temperature. $\mathrm{pH}$ was set by adding drops of concentrated nitric acid onto the solution before the experiment started. At the end of 6 hours, solution aliquots were centrifuged; the supernatant was diluted and analyzed by atomic absorption spectrometry.

\subsection{Data Modeling}

For the kinetics experiments, the most usual models were used, in this case, pseudofirst order (Equation 3) and intraparticle diffusion (Equation 4):

$$
q(t)=q_{e}\left(1-e^{k_{1} t}\right)
$$

where $q_{e}$ is the concentration of the metal in the solid phase during equilibrium in mmol.g ${ }^{-1}$ and $k_{l}$ is the removal rate parameter of the pseudofirst order model in min $^{-1}$.

$$
q(t)=k_{i} \cdot t^{1 / 2}
$$

where $k_{i}$ is the removal rate parameter of the pseudofirst order model in mmol.g ${ }^{-1} \cdot \mathrm{min}^{-}$ $1 / 2$. When the limiting stage of the process is ruled by a very slow intraparticle diffusion mechanism, removal is dependant of the square root of time (Weber and Morris, 1963).

For equilibrium experiments, monocomponent models can't be directly used, The bicomponent equilibrium models of Langmuir (1918), represented by Equation 5, and Langmuir-Freundlich, represented by Equation 6, were used. Both equations are written for a single component: 


$$
q_{1}^{*}=\frac{q_{m} \cdot b_{1} \cdot C_{1}}{1+b_{1} \cdot C_{1}+b_{2} \cdot C_{2}}
$$

where $q^{*}$ is the concentration of the ion on the solid phase, $q_{m}$ is the total capacity of the clay's adsorption, including both ions, in mmol. $\mathrm{g}^{-1}, b_{i}$ is the ratio between adsorption and desorption rates and $C_{i}$ is the concentration of the ion on the liquid phase, in mmol. $\mathrm{L}^{-1}$. The indexes 1 and 2 stand for each component adsorbed.

The Langmuir multicomponent isotherm has had limited success, leading many authors to introduce a power law expression on Freundlich form, leading to the Langmuir-Freundlich model (Ruthven, 1984):

$$
q_{1}^{*}=\frac{q_{m} \cdot b_{1} \cdot\left(C_{1}\right)^{k_{1}}}{1+b_{1} \cdot\left(C_{1}\right)^{k_{1}}+b_{2} \cdot\left(C_{2}\right)^{k_{2}}}
$$

where $\mathrm{k}_{1}$ and $\mathrm{k}_{2}$ are the Freundlich constants.

The modeling of the equilibrium models to experimental data was attempted by minimizing the quadratic error, using the Downhill Simplex method (NELDER and MEAD, 1965).

$$
\sum_{n=1}^{n \operatorname{Comp}} \sum_{\mathrm{p}=1}^{\mathrm{nExp}}\left[\left(q_{n}\right)_{p}^{\text {Exp }}-\left(q_{n}\right)_{p}^{\text {Mod }}\right]^{2}
$$

where $\left(q_{n}\right)_{p}^{\text {Exp }}$ is the experimental concentration on the solid phase, $\left(q_{n}\right)_{p}^{\text {Mod }}$ is the concentration on the solid phase obtained through the model, $n E x p$ is the number of experimental points and $n$ Comp is the number of components in the solution. In this case, $n$ Comp $=2$.

Using Microsoft Excel's Solver, parameters were optimized while keeping the capacity of the clay's adsorption, $\mathrm{q}_{\mathrm{m}}$, at values that were close to the expected value of the parameter, based on data. The other parameters, $b_{1}, b_{2}, k_{1}$ and $k_{2}$ were kept free to calculate. The fit was complete when $\mathrm{R}^{2}$ reached an optimal value.

\section{MATERIALS AND METHODS}

\subsection{Kinetics}

The adsorption kinetic curves were obtained for three different initial concentrations of copper and zinc. The adsorption curves and the kinetic models' adjustments are illustrated on Figure 1 (A-C). All of the experiments showed quick saturation time, reached in less than 30 minutes, as shown in Figure 1.

As can be observed in Figure 1B, the initial concentration of zinc ions is slightly higher while the amount adsorbed at equilibrium of each ion is about the same, which shows that the acidified Fluidgel has higher affinity for copper. Although copper presents higher affinity for 
the material, Figures $1 \mathrm{~A}$ and $1 \mathrm{C}$ show that the selectivity of the ions is directly proportional to the solute concentration. The work of Almeida Neto (2013) has also shown higher affinity of copper to Fluidgel clay on monocomponent experiments: in batch sorption, for initial concentrations of copper and zinc of $1.57 \mathrm{mmol} . \mathrm{L}^{-1}$ and $1.53 \mathrm{mmol} . \mathrm{L}^{-1}$, respectively, the maximum adsorbed quantity was $0.08 \mathrm{mmol} . \mathrm{g}^{-1}$ and $0.06 \mathrm{mmol} . \mathrm{g}^{-1}$. The equilibrium isotherms showed similar results: the parameter $a$ from the Freundlich model reached 0.213 for copper and 0.170 for zinc. Although this parameter and the removal capacity of the material are not equivalent, since Freundlich's model does not comprehend saturation of the material, they are directly related.
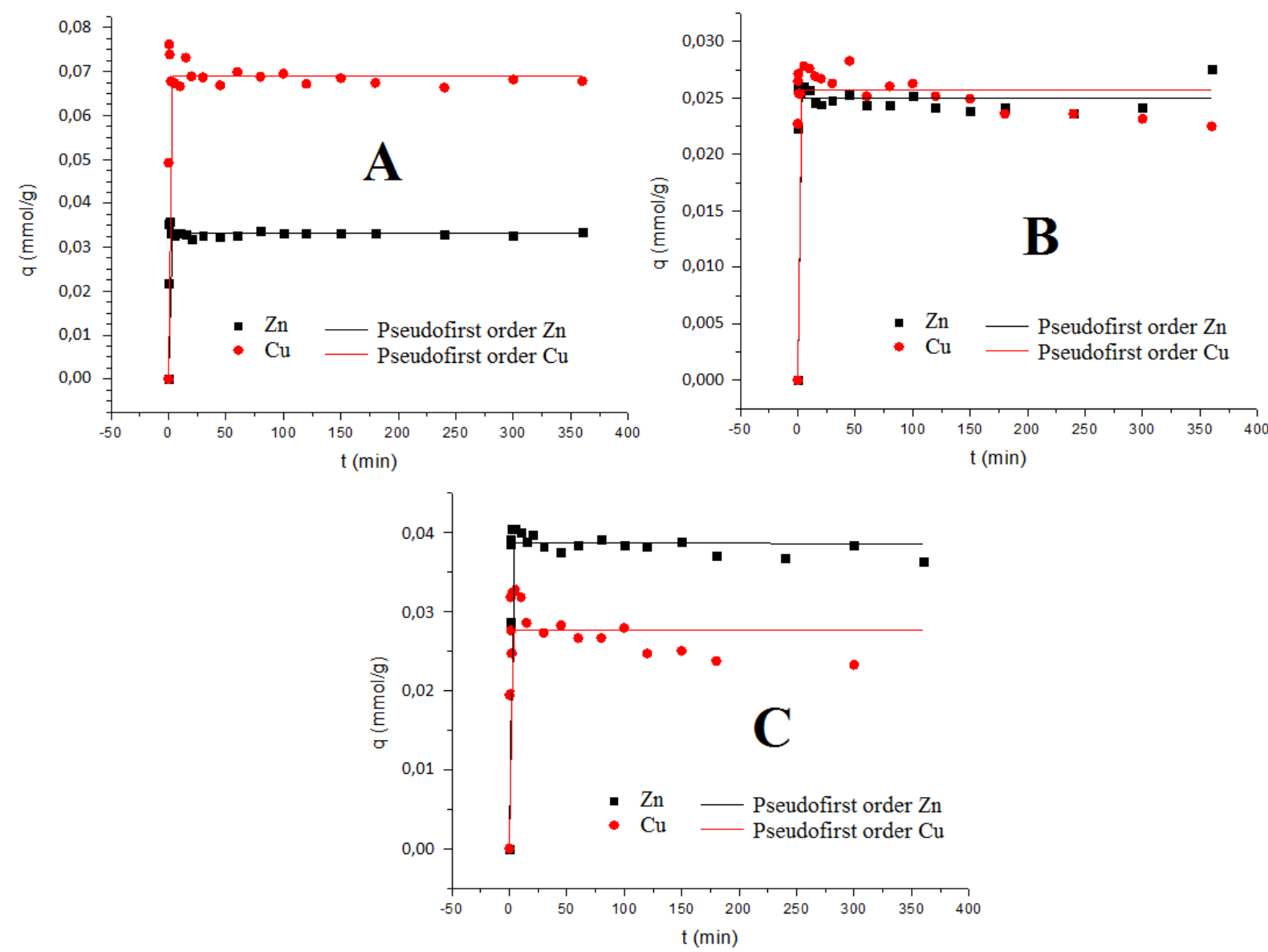

Figure 1 - Kinetic curves obtained and non-linear curve fit of pseudofirst order. Zinc and copper initial concentrations are, respectively, (A) $0.540 \mathrm{mmol} . \mathrm{L}^{-1}$ and $0.896 \mathrm{mmol. \textrm {L } ^ { - 1 }}$; (B) 0,395 mmol. $\mathrm{L}^{-1}$ and 0,333 mmol.L $\mathrm{L}^{-1}$; (C) 0,689 mmol.L $\mathrm{L}^{-1}$ and 0,505 mmol. $\mathrm{L}^{-1}$.

The parameters obtained by the models' fits of the pseudofirst order and intraparticle diffusion are can be found on Table 1. The intraparticle diffusion is one of the impulsive forces in the first 30 seconds of process, thus the modeling was fit in this time period. After that, the kinetic curve tends to the equilibrium state.

Intraparticle diffusion modeling confirms selectivity behavior. The removal parameter $\mathrm{k}_{\mathrm{i}}$ increases when one of the ions is the majoritary compound on solution and, when zinc concentration is slightly higher, $\mathrm{k}_{\mathrm{i}}$ is roughly equal for both metals. 
The equilibrium concentration for each ion, $\mathrm{q}_{\mathrm{e}}$, was very consistent with empirical values, reaching $0.0691 \mathrm{mmol} . \mathrm{g}^{-1}$ for copper and $0.0385 \mathrm{mmol} . \mathrm{g}^{-1}$ for zinc. The removal rate parameter $\mathrm{k}_{1}$ showed higher values for lower initial concentrations (Experiment $\mathrm{B}$ ), which indicates good adsorption at low concentrations. Also, removal reached $75.8 \%$ for copper and $62.9 \%$ for zinc, proving the clay's efficiency at low concentrations of these adsorbates.

Table 1 - Parameters obtained through the pseudofirst order and intraparticle diffusion models' fits to the experimental data ( ${ }^{*}$ Mean values)

\begin{tabular}{|cc|cccc|cc|}
\hline \multirow{2}{*}{ Experiment } & \multicolumn{4}{|c|}{ Pseudofirst order } & \multicolumn{2}{c|}{ Intraparticle diffusion } \\
\cline { 3 - 8 } & Metal & $\begin{array}{c}\mathrm{q}_{\mathrm{e}} \\
\left(\mathrm{mmol.g}^{-1}\right)\end{array}$ & $\begin{array}{c}\mathrm{k}_{1} \\
\left(\mathrm{~min}^{-1}\right)\end{array}$ & $\mathrm{R}^{\mathbf{2}}$ & \% Removal & $\begin{array}{c}\mathrm{k}_{\mathrm{i}} \\
\left(\mathrm{mmol}^{-1} \cdot \mathrm{min}^{-1 / 2}\right)\end{array}$ & $\mathrm{R}^{\mathbf{2}}$ \\
\hline \multirow{2}{*}{$\mathrm{A}$} & Copper & 0.0691 & 15.019 & 0.973 & 75.8 & 0.1047 & 0.855 \\
& Zinc & 0.0332 & 12.977 & 0.985 & 61.1 & 0.0488 & 0.885 \\
\hline \multirow{2}{*}{$\mathrm{B}$} & Copper & 0.0257 & 25.915 & 0.926 & 72.7 & 0.0545 & 0.823 \\
& Zinc & 0.0250 & 26.815 & 0.970 & 62.9 & 0.0531 & 0.815 \\
\hline \multirow{2}{*}{$\mathrm{C}$} & Copper & 0.0275 & 16.090 & $<0.9$ & 50.0 & 0.0635 & 0.997 \\
& Zinc & 0.0385 & 16.238 & 0.982 & 54.5 & 0.0780 & 0.933 \\
\hline
\end{tabular}

In Experiment $\mathrm{B}$, the final concentrations of copper and zinc in the fluid phase were below the limits established by the Brazilian National Environmental Council (CONAMA), which dictates $5.0 \mathrm{mg} . \mathrm{L}^{-1}$ of $\mathrm{Zn}\left(0.076 \mathrm{mmol} . \mathrm{L}^{-1}\right)$ and $1.0 \mathrm{mg} . \mathrm{L}^{-1}$ of $\mathrm{Cu}(0.016 \mathrm{mmol} / \mathrm{L})$, respectively, as the maximum standard for each metal (CONAMA 430, 2011). In Experiments $\mathrm{A}$ and $\mathrm{C}$, it would be required further removal procedure for the residue in order to achieve proper disposal concentration.

\subsection{Equilibrium}

The equilibrium isotherms were taken for the temperatures of $293 \mathrm{~K}, 313 \mathrm{~K}$ and $333 \mathrm{~K}$, in which the initial concentrations were kept constant for the three experiments. The models provided a good fit to the experimental data. Both models fit the experimental data well, although the Langmuir-Freundlich model provides a better fit. Although the latter is not thermodynamically consistent, it has shown great results for empirical correlations of binary equilibrium data of gases on molecular sieve adsorbents, of metal ions on algae and single equilibrium data onto alternative adsorbent (Klenübing, 2009; Souza, 2013; Ruthven, 1984).

Parameters obtained from both equilibrium models can be found on Table 2. The experimental data for the isotherms and the curves obtained through the equilibrium models can be found on Figure 2 (A-B). The curves show that the adsorption of copper has the highest maximum concentration at $313 \mathrm{~K}$, while $\mathrm{q}_{\mathrm{m}}$ for zinc seems to just slightly higher at $313 \mathrm{~K}$ than $293 \mathrm{~K}$. Furthermore, contrary to kinetic studies, zinc seems to have stronger interaction with Fluidgel clay than copper, according to the $\mathrm{q}_{\mathrm{m}}$ values. However, equilibrium studies did not show any result with copper retention close to $0.07 \mathrm{mmol} . \mathrm{g}^{-1}$, observed on kinetic experiment A. This indicates that further research is necessary, since important experimental points might be missing.

Figure 2(A-B) shows that the equilibrium isotherms have linear behavior which, according to McCabe et al (2000), does not show the adsorbent's maximum capacity and is 
usually favorable for higher concentrations of adsorbate. It is very likely, however, that the region observed represents the isotherm predicted by Henry's Law, where concentrations in aqueous and solid phases are linearly correlated.

Table 2 - Parameters of equilibrium models for zinc and copper adsorption onto Fluidgel clay

\begin{tabular}{|c|c|c|c|c|c|c|c|}
\hline \multirow{2}{*}{ Model } & \multirow{2}{*}{ Parameter } & \multicolumn{2}{|c|}{$293 \mathrm{~K}$} & \multicolumn{2}{|c|}{$313 \mathrm{~K}$} & \multicolumn{2}{|c|}{$333 \mathrm{~K}$} \\
\hline & & Copper & Zinc & Copper & Zinc & Copper & Zinc \\
\hline \multirow{3}{*}{ Langmuir } & $\begin{array}{c}\mathrm{q}_{\mathrm{m}} \\
(\mathrm{mmol} / \mathrm{g})\end{array}$ & \multicolumn{2}{|c|}{0.165} & \multicolumn{2}{|c|}{0.215} & \multicolumn{2}{|c|}{0.085} \\
\hline & $\mathrm{b}(\mathrm{L} / \mathrm{mmol})$ & 0.084 & 0.136 & 0.092 & 0.110 & 0.131 & 0.106 \\
\hline & $\mathrm{R}^{2}$ & 0.90 & 0.89 & 0.92 & 0.89 & 0.92 & $\begin{array}{c}> \\
0.99\end{array}$ \\
\hline \multirow{4}{*}{$\begin{array}{l}\text { Langmuir- } \\
\text { Freundlich }\end{array}$} & $\begin{array}{c}\mathrm{q}_{\mathrm{m}} \\
(\mathrm{mmol} / \mathrm{g})\end{array}$ & \multicolumn{2}{|c|}{0.250} & \multicolumn{2}{|c|}{0.295} & \multicolumn{2}{|c|}{0.125} \\
\hline & $\mathrm{b}(\mathrm{L} / \mathrm{mmol})$ & 0.058 & 0.065 & 0.053 & 0.064 & 0.080 & 0.062 \\
\hline & $\mathrm{k}$ & 1.076 & 1.657 & 1.356 & 1.594 & 1.359 & 0.709 \\
\hline & $\mathrm{R}^{2}$ & 0.96 & 0.97 & 0.93 & 0.97 & 0.94 & $\begin{array}{c}> \\
0.99\end{array}$ \\
\hline
\end{tabular}

The work of Almeida Neto (2013) has shown that acidified Fluidgel has increasing $\mathrm{q}_{\mathrm{m}}$ values for copper with temperature and decreasing values for zinc, both being clearly favorable to adsorption at low concentrations. It is possible that further research lead to similar results, since the kinetic results in this study indicate that there has not been competition between the copper and zinc ions.
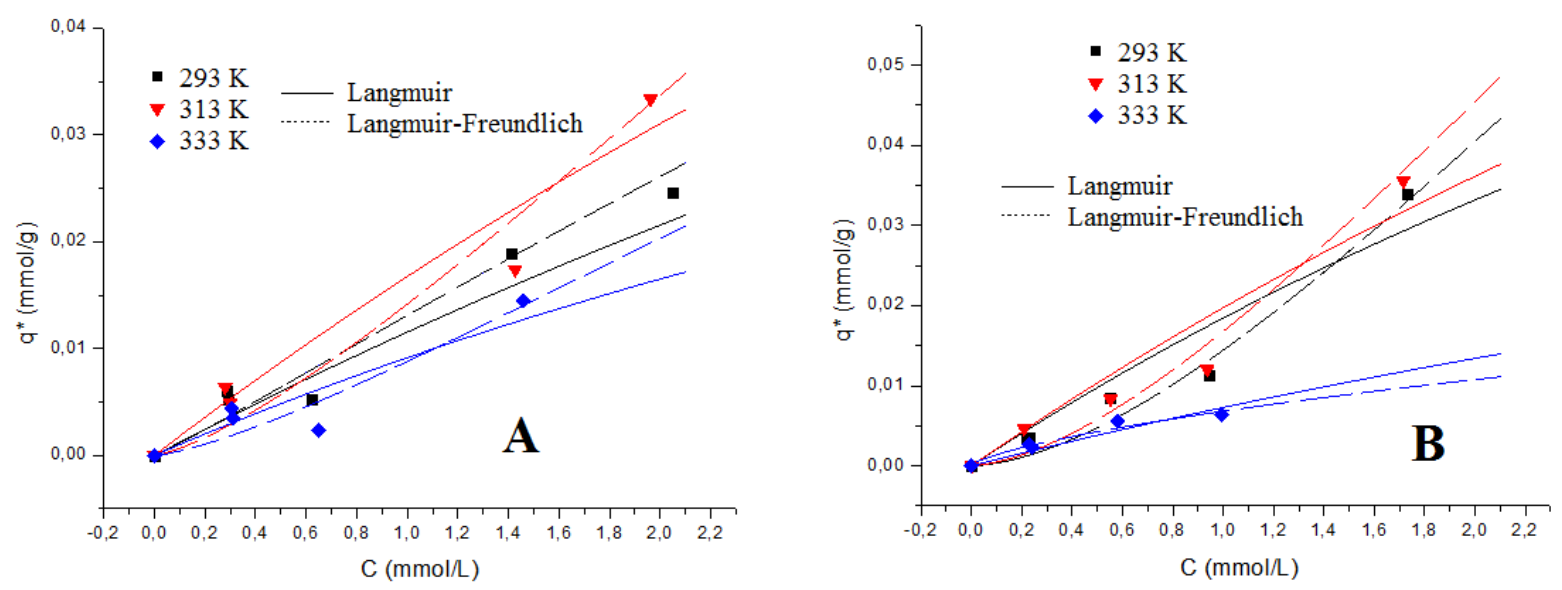

Figure 2 - Equilibrium curves and non-linear modeling fit for (A) copper and (B) zinc for the isotherms of $293 \mathrm{~K}, 313 \mathrm{~K}$ and $333 \mathrm{~K}$.

\section{CONCLUSION}

Kinetic studies have shown good removal capacity of heavy metals by Fluidgel clay chemically treated with acid. Equilibrium has been reached consistently under 30 minutes and removal of the ions has reached $75.8 \%$ for $\mathrm{Cu}$ and $62.9 \%$ for $\mathrm{Zn}$, respectively, in mixture. Kinetic studies have also agreed with previous study in single component systems (Almeida Neto, 2013), indicating that there was not competition present. Considering the low adsorbent 
cost, ease to prepare and manipulate the material and simplicity of the process, there are high indications that Fluidgel clay is a promising material for metal removal in single and binary systems. Equilibrium studies have shown optimal values for metal removal at $313 \mathrm{~K}$, according to both Langmuir and Langmuir-Freundlich models, which provided good correlation to experimental data. However, results indicated that the equilibrium was more favorable at higher concentrations and that zinc had higher affinity for the adsorbent, while kinetic studies clearly showed that the major adsorbed component was copper. This indicates that more research is necessary to correctly comprehend and model equilibrium behavior of the bicomponent system.

\section{REFERENCES}

ALLOWAY, B. J. Heavy metals in soil. Glasgow: Chapman \& Hall, p. 339, 1990.

ALMEIDA NETO, A. F. Avaliação de argila sódica como adsorvente na remoção e eluição de íons cobre e zinco. Campinas, University of Campinas, Thesis (postdoctorate), 2013.

CONAMA, Brazilian Ministry of Environment. Conditions and standards for wastewaters discharge. Resolution No. 430, 2011. (In Portuguese)

KLEINÜBING, S. J. Bioadsorção competitiva dos íons níquel e cobre em alginato e alga marinha Sargassum filipendula. Campinas, University of Campinas, Thesis (PhD), 2009.

LANGMUIR, I. The adsorption of gases on plane surfaces of glass, mica and platinum. Amer. Chem. Society, 1918. 40:1361-1403.

NELDER, J. A.; MEAD, R. A.; A simplex method for function minimization. The Comp. J., v. 7, n. 4, p. 308-313, 1965.

McCABE, W. L.; SMITH, J. C.; HARRIOT, P. Unit Operations of Chemical Engineering. $6^{\text {th }}$ ed., McGraw Hill, 2000.

NISHIKAWA, E.; ALMEIDA NETO, A. F.; VIEIRA, M. G. A. Equilibrium and thermodynamic studies of zinc adsorption on expanded vermiculite. Adsorp. Sci. and Tech., v. 30, n. 8/9, p. 759-772, 2012.

RUTHVEN, D. M. Principles of Adsorption and Adsorption Processes. New York, John Wiley \& Sons, Inc., 1984.

VIEIRA, M. G. A.; ALMEIDA NETO, A. F.; GIMENES, M. L.; DA SILVA, M. G. C. Removal of nickel on Bofe bentonite calcined clay in porous bed. J. Hazard. Mater., v. 176, p. 109-118, 2010a.

VIEIRA, M. G. A.; ALMEIDA NETO, A. F.; GIMENES, M. L.; DA SILVA, M. G. C. Sorption kinetics and equilibrium for the removal of nickel ions from aqueous phase on calcined Bofe bentonite clay. J. Hazard. Mater., v. 177, p. 362-371, 2010 b.

VIEIRA, M. G. A.; ALMEIDA NETO, A. F.; DA SILVA, M. G. C.; NÓBREGA, C. C.; MELO FILHO, A. A. Characterization and use of in natura and calcined rice husks for biosorption of heavy metals ions from aqueous effluents. Brazil. J. of Chem. Eng., v. 29, p. 619-633, 2012.

SOUZA, R. S. Avaliação da Lama Vermelha na Remoção de Derivados de Petróleo - Benzeno, Tolueno e Xileno (BTX). Campinas, University of Campinas, Thesis (PhD), 2013.

WEBER, W. G.; MORRIS, J. C. Kinetics of adsorption on carbon from solution. J. Sanitary Eng., Division ASCE, v. 89, p. 31-60, 1963.

\section{ACKNOWLEDGEMENTS}

The authors thank CNPq, FAPESP and SAE/UNICAMP for financial support. 